Sharif University of Technology
Scientia Iranica
SCIENTIA
IRAN I CA

\title{
Numerical simulation of a novel Trombe wall-assisted desiccant wheel
}

\author{
M. Bahramkhoo ${ }^{a}$, K. Javaherdeh ${ }^{\mathrm{b}, *}$, F. Atabi ${ }^{\mathrm{a}}$, and A. Emamzadeh \\ a. Faculty of Natural Resources and Environment, Science and Research Branch, Islamic Azad University, Tehran, P.O. Box \\ $14515 / 775$, Iran. \\ b. Faculty of Mechanical Engineering, University of Guilan, Rasht, P. Code 4199613776, Iran. \\ c. Department of Petroleum and Chemical Engineering, Science and Research Branch, Islamic Azad University, Tehran, P.O. Box \\ $14515 / 775$, Iran.
}

Received 17 October 2018; received in revised form 4 January 2019; accepted 26 January 2019

\section{KEYWORDS \\ Desiccant; \\ Trombe wall; \\ Humidity; \\ Airflow; \\ Heat transfer.}

\begin{abstract}
In the present study, a novel Trombe wall-assisted desiccant wheel system is modeled, in which the trombe wall is divided into three equal parts and provides the heat required for regeneration of the desiccant wheel. Separate mathematical models have been proposed for different components of the system such as desiccant wheel and Trombe wall. The mathematical models of different parts have been assembled. Effects of the geometrical parameters of the Trombe wall on the regeneration temperature of the desiccant wheel have been investigated based on the integrated model. The results of the present study for some special cases have been compared with results available in open literature. The optimal surface area of the Trombe wall has been extracted according to the parameters of the desiccant wheel. Results show that the solar energy received by the Trombe wall is $600-740 \mathrm{~W} / \mathrm{m}^{2}$ ( 1 May- 15 August) in the warm and humid climate of Gilan (Iran), the temperature of the wall surface is obtained $77-86^{\circ} \mathrm{C}$, and the outlet temperature of regeneration air stream from Trombe wall is obtained $60-70^{\circ} \mathrm{C}$; however, the output humidity of the desiccant wheel is reduced from $23 \mathrm{~g}_{w} / \mathrm{kg}_{a}$ to $10-12 \mathrm{~g}_{w} / \mathrm{kg}_{a}$ in the studied region (Gilan, Iran).
\end{abstract}

(C) 2019 Sharif University of Technology. All rights reserved.

\section{Introduction}

The use of solar energy as a clean and sustainable source for cooling systems has recently attracted the attention of many researchers, because the abundance of solar energy in the environment coincides with the time periods of the year that the need for cooling is very

*. Corresponding author. Tel.: 013336902748

E-mail addresses: m_bahramkhoo@yahoo.com ( $M$.

Bahramkhoo); javaherdeh@guilan.ac.ir (K. Javaherdeh);

far-atabi@jamejam.net (F.Atabi); emamzadeh@srbiau.ac.ir (A. Emamzadeh)

doi: $10.24200 /$ sci.2019.52042.2502 high. Desiccant wheel cooling systems that operate on the basis of absorption and evaporative cooling moisture can also use solar thermal energy. Ge et al. [1] presented a review of solar-powered rotary desiccant wheel cooling systems. Results of their study showed that hybrid solar-powered rotary desiccant wheel cooling systems could achieve significant energy saving and efficiency in comparison with vapor compression systems. Jani et al. [2] also presented a review of solid desiccant air conditioning and discussed some of the recently proposed configurations of desiccant air conditioning systems and, among them, solarassisted solid desiccant evaporative cooling systems. The same authors, Jani et al. [3], recently presented 
a critical review of the application of solar energy as a renewable regeneration heat source in solid desiccant vapor compression hybrid cooling systems. They provided substantial data about the configuration and performance of different solar-assisted solid desiccant air conditioning systems.

Due to the flexibility of the application and efficiency of desiccant cooling systems, studying their characteristics and performance and also investigating the potentiality of using them in different climates have engrossed a great deal of attention among researchers recently. Hatami et al. [4] presented a mathematical procedure to optimize the solar collector surface in solar desiccant wheel cycle. In their proposed cooling cycle, the thermal solar energy is used to provide the energy required for regeneration of air of desiccant wheel cycle. Tsujiguchi et al. [5] performed a feasibility study of simultaneous heating and dehumidification using an adsorbent desiccant wheel with humidity swing. Kabeel and Abdelgaied [6] investigated the effects of solar energy and Phase Change Material (PCM) on the energy saving of a desiccant air conditioner by means of a numerical approach. They proposed three configurations of a desiccant air conditioner and performed a comparative analysis between them in the same ambient conditions to understand which one of them is more efficient for energy-saving purposes. Das and Jain [7] investigated solar-assisted liquid desiccant cooling systems with indirect contact dehumidifier experimentally. They assessed the overall performance in terms of its dehumidification effectiveness, moisture removal rate, cooling capacity, and thermal COP. Theoretical modeling and experimental study of the air thermal conditioning process of a heat pump-assisted solid desiccant cooling system was presented by Nie et al. [8]. Gadalla and Saghafifar [9] proposed three novel two-stage desiccant air conditioning cooling systems and investigated them in hot and humid climates. Kumar and Yadav [10] performed an experimental investigation of the solar-powered desiccant cooling system by using composite desiccant " $\mathrm{CaCl}_{2} /$ jute". They found that the average dehumidification rate increased by $54.1 \%$ when using circulating cooling water. Ahmadzadehtalatapeh [11] studied the feasibility of a solar-assisted desiccant evaporative cooling system for office buildings in Iran.

Performance analysis of solar-assisted desiccant cooling systems has been the topic of much research recently. El-Agouz and Kabeel [12] investigated the performance of an air conditioning desiccant for different weather conditions. They studied the desiccant system with a collector, and found that the coefficient of performance decreased with an increase in the input humidity ratio and regeneration temperature. Wrobel et al. [13] investigated the performance of a solar air conditioning system in different regions. In their study, a system, which was based on solar and geothermal energy, was investigated. This technology was implemented in Hamburg as a pilot experiment. The combination of the desiccant wheel and the employed exchangers led to a high-efficiency air conditioning system. Sopian et al. [14] studied a solar desiccant wheel in a warm and humid region. They used the TRNSYS software to model a cooling system equipped with a solar collector and a storage reservoir. More recently, Abbassi et al. [15] carried out a comparative performance analysis of different solar desiccant dehumidification systems. They used TRNSYS software to analyze and compare the transient performance of different configurations of solar desiccant cooling systems on the basis of the concept of finite-time thermodynamics. Salarian et al. [16] introduced a liquid desiccant evaporation cooling air conditioning system and studied its performance. Jani et al. in a series of papers [17-20] investigated different aspects of performance of solar-assisted desiccant cooling systems.

There are different ways of capturing solar energy in order to use it as a source of regeneration energy required in solid desiccant cooling systems, and the most fashionable of these capturing methods is the use of solar collectors, which can be employed in widespread applications with a great degree of flexibility for different climatic conditions. For example, evacuated tubes, PVT, and flat plate collectors have been proposed for some configurations of solar-assisted desiccant cooling systems in this regard [1].

Another way of capturing solar energy for household applications is the utilization of solar walls. Solar walls are an example of passive solar energy systems with well-known practical advantages. These walls absorb solar energy by an absorber. In a confined space, the resulting hot air moves upward through free convection and can be utilized as a source of lowgrade solar energy for household and air conditioning purposes. Solar walls and their advantages, potential uses, and performance have been discussed by many authors so far. Stritih and Medved [21] investigated the mathematical model of PCM material, heating of air for the simulation of wall functioning, and a Type 58 subprogram as a module for the program package TRNSYS.

Shen et al. [22] studied the behavior of classical and composite solar walls. Utilizing TRNSYS software, they performed numerical analysis on the thermal performances of passive solar systems, a classical Trombe wall and a composite Trombe-Michel wall. FernándezGonzález [23] analyzed the thermal performance and comfort conditions of five different passive solar heating strategies in the United States Midwest. Stazi et al. [24] studied the possibility of solar walls and their performance in Italian climates. Stazi et al. [25] 
also studied the behavior of solar walls in residential buildings with different insulation levels by means of numerical and experimental methods.

In the present study, for the first time, the use of a Trombe wall as a source of regeneration energy of solid desiccant wheel system has been investigated. A new configuration has been suggested to utilize the passive low-grade solar energy for a solar-wallassisted desiccant wheel system, and a mathematical model has been used to optimize the Trombe wall area based on the other performance parameters of the proposed configuration. In short, the main thesis of the present study is to apply the naturally heated air of the Trombe wall to regenerate the desiccant wheel. The effect of various parameters on the performance of desiccant wheel system and the proposed Trombe wall has been investigated and analyzed by means of the mathematical model of the present study. Each part of the system (i.e., Trombe wall, desiccant wheel) has been analytically modeled; then, all parts are assembled to form the main problem of the current study, that is, the optimization of the Trombe wall area with respect to the physical structure of the wall and other parameters involved in its performance.

\section{Description of the Trombe wall-desiccant system}

In the present study, a Trombe wall-desiccant system has been introduced for use in humid climates. The hybrid system consists of a desiccant wheel and a Trombe wall to provide the heat energy needed for the regeneration of the desiccant wheel. A schematic view of the desiccant wheel system of the present study is shown in Figure 1. This figure shows that two airflows including the process flow (1-2) and regeneration airflow (3-4) go through the desiccant wheel system. When the exhaust temperature of the Trombe wall channel is lower than the dehumidification temperature $(\leq 60)$, the emergency heater is used. The optimum temperature of $60-90^{\circ} \mathrm{C}$ is considered for the regeneration desiccant absorbent [26]. In the regeneration air stream, the air is heated by a Trombe wall mechanism and, then, used as the recycling air,

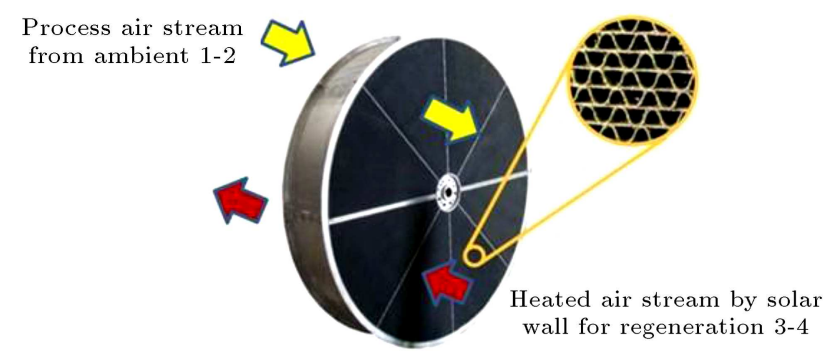

Figure 1. Desiccant wheel system, adsorption airflow (1-2), and regeneration airflow (3-4). and the emergency heater is used during the hours with no solar radiation.

\section{Mathematical analysis of the system}

For the sake of simplicity, the desiccant wheel is considered in a way that half of it is exposed to a humid airflow, and the other half is exposed to a dry and hot airflow. Dry air stream flow rate and humid air stream flow rate are assumed identical. Half of the wheel, which is exposed to a wet airflow, is the absorbent section, and the other half, which is exposed to a dry and hot airflow, is called the recovery section. The following assumptions have been considered to analyze the absorbent wheel [27]:

- Vapor diffusion and permeation in the same direction of flow can be neglected;

- There is no difference in temperature and/or humidity in the direction of wheel radius in absorbing mesh;

- The hysteresis of absorption characteristic curve for an absorbent material layer is negligible;

- The thermal and moisture properties of an absorbent matrix are constant;

- Air and absorbent channels are assumed completely insulated thermally and in terms of moisture transfer;

- The coefficients of heat and mass transfer are also assumed constant.

\subsection{Flow model for the process air (1-2)}

Based on the above-mentioned assumptions, the following mathematical model can be used for the desiccant wheel outlet air temperature $T_{\text {out }}$ and dehumidifier effectiveness, $\varepsilon$ [27]:

$$
\begin{aligned}
& T_{\text {out }}=\Pi\left(g_{i}\right), \\
& \varepsilon=\Pi\left(f_{i}\right), \\
& \varepsilon=\frac{\omega_{\text {in }}-\omega_{\text {out }}}{\omega_{\text {in }}},
\end{aligned}
$$

where functions $f_{i}$ and $g_{i}$ are simulation functions that are achieved by means of numerical modeling of the desiccant wheel in order to provide a correlation between different desiccant wheel parameters and outlet temperature, $T_{\text {out }}$, and effectiveness, $\varepsilon$ [27]. These functions are themselves composed of desiccant wheel variables and can be given as follows [4,27]: 


$$
\begin{aligned}
& f_{i=1}\left(T_{d b}\left({ }^{\circ} \mathrm{C}\right)\right)=-0.0001 T_{d b}^{2}-0.0031 T_{d b}+0.8353, \\
& f_{i=2}\left(\omega_{i n}(\mathrm{~g} / \mathrm{kg})\right)=593 \omega_{i n}^{2}-42.13 \omega_{i n}+1.383, \\
& f_{i=3}(N(\mathrm{rph}))=-0.0001 N^{2}+0.0042 N+0.45, \\
& f_{i=4}\left(T_{R e g}(\text { from Trombe wall })\right) \\
& =-0.0001 T_{R e g}^{2}+0.0355 T_{R e g}-0.4924, \\
& f_{i=5}\left(D_{h}(\mathrm{~mm})\right) \\
& =-0.0572 D_{h}^{3}+0.0933 D_{h}^{2}+0.6139 D_{h}-0.092, \\
& f_{i=6}(d t(\mathrm{~mm}))=-21.67 d t^{2}+6.93 d t+1.4, \\
& f_{i=7}(U(\mathrm{~m} / \mathrm{s}))=-0.07 U+0.84, \\
& g_{i=1}\left(T_{d b}\left({ }^{\circ} \mathrm{C}\right)\right)=-0.0001 T_{d b}^{2}+0.0275 T_{d b}+0.7993, \\
& g_{i=2}\left(\omega_{i n}(\mathrm{~g} / \mathrm{kg})\right)=594.48 \omega_{i}^{2}+26.76 \omega_{i}+3.79, \\
& g_{i=3}(N(\mathrm{rph}))=-0.0002 N^{2}+0.0112 N+0.4201, \\
& g_{i=4}\left(T_{R e g}(\text { from Trombe wall })\right) \\
& =-0.0004 T_{R e g}^{2}+0.1255 T_{R e g}+0.6757, \\
& g_{i=5}\left(D_{h}(\mathrm{~mm})\right)=-0.039 D_{h}^{3}+0.026 D_{h}^{2}+0.603 D_{h} \\
& +0.0912 \\
& g_{i=6}(d t(\mathrm{~mm}))=-18.79 d t^{2}+7.92 d t+1.75, \\
& g_{i=7}(U(\mathrm{~m} / \mathrm{s}))=-0.06 U+0.78 \text {. }
\end{aligned}
$$

\subsection{Trombe wall model}

A 3D schematic view of the Trombe wall is shown in Figure 2, and the geometrical parameters of the wall are shown in Figure 3. The Trombe wall is divided into three equal parts. The reason behind this is to achieve a fully developed boundary layer on the top of the wall after the air between the wall and the glass gets warm and goes up in temperature. The wall is composed of a light and solar radiation absorptive surface, appropriate insulation implemented inside the wall, and a glass cover along the southward direction of the building. As its working mechanism, the air between the glass and wall is heated by solar radiation, after which it moves to the top of the wall due to density variations. After passing through a specific duct, the hot air is used to regenerate the matrix network made of silica gel in the desiccant wheel for humidity removal. In this study, a numerical model

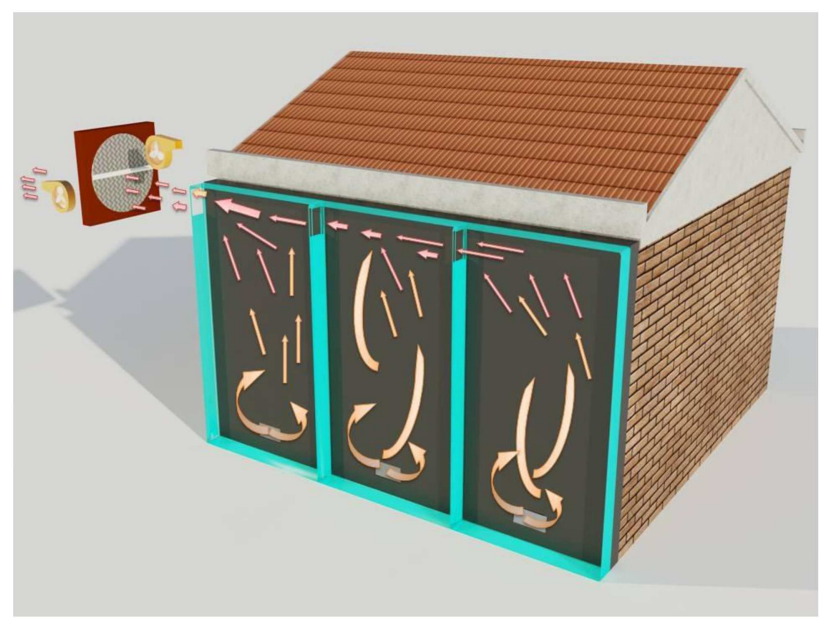

Figure 2. A 3D schematic view of the structure of the Trombe wall.

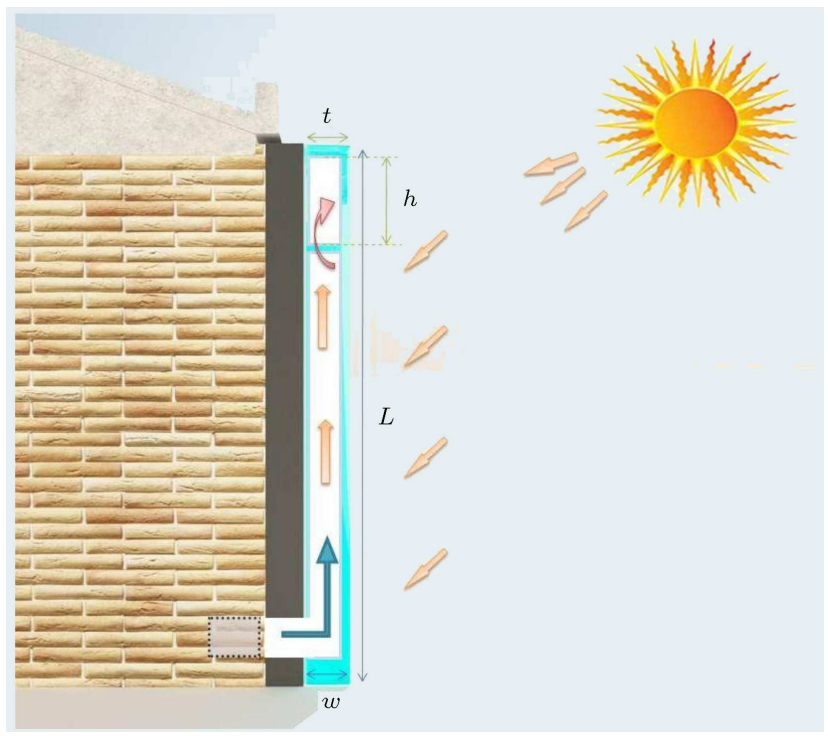

Figure 3. Geometrical parameters of the Trombe wall

is developed for free convection heat transfer with a vertical boundary layer in the space between the wall and glass. Moreover, the buoyancy forces are considered to affect the fluid $[28,29]$. The mathematical model of the solar wall has been derived based on the following assumptions:

- The condition of system behavior is in steady state;

- The airflow in the channel is turbulent and incompressible;

- The temperature of airflow at the inlet of the channel and at the room is assumed to be equal;

- Thermal properties are considered at an average temperature.

3.2.1. Energy equilibrium equation applied to the glass Energy equilibrium equation of the glass is given by 
Mathur et al. [28] as follows:

$\{$ Solar gain energy $\}+\{$ Solar energy reflected from the wall towards the glass $\}=\{$ Convection energy transferred to the air stream in channel\}

$+\{$ Energy dissipated to the environment

from the glass $\}$,

where its mathematical formulation, after some manipulations, can be rendered as follows:

$$
\begin{aligned}
c_{1} T_{\text {glass }} & +c_{2} T_{\text {flow }}+c_{3} T_{\text {wall }}=f_{1}, \\
c_{1}= & \left(h_{\text {win }}+h_{r, \text { glass } \rightarrow \text { sky }}+h_{\text {cond }}\right) A_{\text {glass }} \\
& +A_{\text {glass }} h_{\text {conv }}+A_{\text {wall }} h_{r, \text { wall } \rightarrow \text { glass }}, \\
c_{2}= & -A_{\text {glass }} h_{\text {conv }, \text { glass } \rightarrow \text { air }}, \\
c_{3}= & -A_{w} h_{r, \text { wall } \rightarrow \text { glass }}, \\
f_{1}= & \alpha_{\text {glass }} A_{\text {glass }} I+A_{\text {glass }}\left(h_{\text {co nd }}+h_{\text {win }}\right) T_{\text {air }} \\
& +h_{r, \text { glass } \rightarrow \text { sky }} A_{\text {glass }} T_{\text {air }} .
\end{aligned}
$$

3.2.2. Heat energy equation for a stream in a channel The equation for Trombe wall airflow can also be given as follows:

$\{$ Energy from the wall to the airflow $\}$

$+\{$ Energy from glass to the airflow $\}$

$=\{$ Energy transferred to the airflow in channel $\}$,

where its mathematical formulation, after some manipulations, can be given as [28]:

$$
\begin{aligned}
c_{4} T_{\text {glass }}+c_{5} T_{\text {flow }}+c_{6} T_{\text {wall }}=f_{2}, \\
c_{4}=h_{\text {conv, glass } \rightarrow \text { air }} A_{\text {glass }}, \\
c_{5}=-h_{\text {conv,wall } \rightarrow \text { air }} A_{\text {wall }} \\
\\
\quad-h_{\text {conv, glass } \rightarrow \text { air }} A_{\text {glass }}-\left(\dot{m} C_{p} / \omega\right), \\
c_{6}=h_{\text {conv,wall } \rightarrow \text { air }} A_{\text {wall }}, \\
f_{2}=-\dot{m} C_{p} T_{r} / \omega .
\end{aligned}
$$

\subsubsection{Energy equilibrium equation applied to the absorption of the wall}

Based on the same method, the energy balance equa- tion for the absorption of the wall and its mathematical representation are as follows:

\{Amount of absorbed solar energy

$=\{$ Amount of energy from wall to glass through convection $\}+\{$ heat transfer from the wall to the airflow in channel\}.

Therefore:

$$
\begin{aligned}
& c_{7} T_{\text {glass }}+c_{8} T_{\text {flow }}+c_{9} T_{\text {wall }}=f_{3}, \\
& c_{7}=-h_{r, \text { wall } \rightarrow \text { glass }} A_{\text {wall }}, \\
& c_{8}=-h_{\text {conv }, \text { wall } \rightarrow \text { air }} A_{\text {wall }}, \\
& c_{9}=h_{r, \text { wall } \rightarrow \text { glass }} A_{\text {wall }}+h_{\text {conv }, \text { wall } \rightarrow \text { air }} A_{\text {wall }} \\
& \quad+h_{\text {cond } 1} A_{\text {wall }}, \\
& f_{3}=\alpha_{\text {wall }} \tau_{\text {glass }} A_{\text {wall }} I+h_{\text {cond } \simeq 0} A_{\text {wall }} T_{\text {room }} .
\end{aligned}
$$

Eqs. (5)-(7) constitute a recursive system of equations, and the temperatures of the glass, wall, and air stream are found in the solution to these three equations simultaneously. The three above-mentioned equations are solved by applying an iterative method in which an initial guess is used to begin the solving process. The airflow properties inside the channel vary with temperature. The thermodynamic properties of airflow are updated with converging temperature values. The heat transfer coefficients are obtained using the Stefan-Boltzmann law, Newton's law of cooling, and Fourier's law as follows [30]:

$$
\begin{aligned}
h_{r w-g} & =\frac{\sigma\left(T_{w}+T_{g}\right)\left(T_{w}^{2}+T_{g}^{2}\right)}{\left(\frac{1-\varepsilon_{g}}{\varepsilon_{g}}\right)+\left(\frac{1-\varepsilon_{w}}{\varepsilon_{w}}\right)+\left(\frac{1}{F_{w-g}}\right)}, \\
h_{r g-s} & =\frac{\sigma \varepsilon_{g}\left(T_{g}+T_{\mathrm{sky}}\right)\left(T_{g}^{2}+T_{\mathrm{sky}}^{2}\right)\left(T_{g}-T_{\mathrm{sky}}\right)}{T_{g}-T_{a}} .
\end{aligned}
$$

The sky temperature and convection coefficient of wind are determined through Duffie-Beckman equations as follows [30]:

$$
T_{\mathrm{sky}}=0.0552 T_{a}^{1.5}, \quad \text { and } \quad h_{\mathrm{wind}}=2.8+3.0 \mathrm{~V} .
$$

The convective heat transfer coefficients for the glass are obtained as:

$$
h_{\mathrm{cond}}=\frac{1}{\left(\frac{1}{1 / h o}\right)+\left(\frac{\Delta x_{g}}{k_{g}}\right)} .
$$

The heat transfer coefficient for the airflow in the 
channel and mass flow rate of the airflow [28] and the air exchange rate $(\mathrm{ACH})$ are as follows [26]:

$$
\begin{aligned}
& h_{\mathrm{conv}}=\frac{\mathrm{Nu} k_{f}}{L}, \\
& \dot{m}=\frac{C_{d} \rho_{f} A_{0}}{\sqrt{1+\left(\frac{A_{0}^{2}}{A_{i}^{2}}\right)}} \sqrt{2 g L_{c}\left(\frac{T_{f}}{T_{r}}-1\right)}, \\
& \mathrm{ACH}=\frac{\dot{V} \times 3600}{\text { room total volume }} .
\end{aligned}
$$

The relations that are used to calculate the heat transfer coefficients between air flowing in the channel and both absorber and glass are given as [31]:

$$
\begin{aligned}
& \mathrm{Nu}=0.68+\left(0.67 \mathrm{Ra}^{0.25}\right) /\left(\left(1+(0.492 / \mathrm{Pr})^{9.16}\right)^{4.9},\right. \\
& R_{a}=\mathrm{GrPr}=\left(\left(g \beta T L_{c}^{3}\right) / \nu^{2}\right) \mu C_{p} / k_{f}, \\
& \mu_{f}=1.846 \times 10^{-5}+0.00472 \times 10^{-5}\left(T_{m}-300\right), \\
& k_{f}=0.0263+0.000074\left(T_{m}-300\right), \\
& C_{p}=1007+0.004\left(T_{m}-300\right), \\
& \operatorname{Pr}=\mu C_{p} / k_{f}, \\
& T_{m}=\left(T_{g}+T_{w}\right) / 2, \\
& \beta=1 / T_{m}, \\
& \Delta T=T_{w}-T_{f} .
\end{aligned}
$$

\section{Validation of results}

In order to obtain the numerical results of the present study, a set of variables must be determined as input variables of the problem such as the environmental conditions of Point (1), the heated exhaust air temperature of the Trombe wall at Point (3), and other physical and geometrical parameters. which will be given in this section. The experimental data of Kodama et al. [32] and Heidarinejad and Pasdarshahri [33] are used to validate the mathematical model of the desiccant wheel (Table 1). The results of the mathematical model and the experimental of the previous studies are acceptably consistent. It has been assumed that the mass flow rate of the process and recycling air are both equal to $800 \mathrm{~kg} / \mathrm{h}$. The initial parameters are given as $T_{d b}=35^{\circ} \mathrm{C}, \omega_{i n}=23 \mathrm{~g}_{w} / \mathrm{kg}_{a}, T_{w b}=29^{\circ} \mathrm{C}, R H=90 \%$, and $P=1013.2 \mathrm{mbar}, U=1.5 \mathrm{~m} / \mathrm{s}$, and $L$ (wheel length) $=0.2 \mathrm{~m}$.

As mentioned earlier, the Trombe wall is made of three similar parts. Each part is $6 \mathrm{~m}$ high, $3 \mathrm{~m}$ wide, and $0.30 \mathrm{~m}$ air gap. There are three inlets of air at the bottom of the wall, each of which has an area size of $0.2 \mathrm{~m} \times 0.5 \mathrm{~m}$. To determine the Trombe wall outlet temperature, the energy equations governing the Trombe wall are solved using an iterative method, and glass temperature, absorber temperature, and the airflow temperature in the channel are obtained. These three temperatures are the major parameters for the Trombe wall model. The hot temperature of the channel exhaust is obtained by solving the governing equations of the Trombe wall model. In order to validate the results, the results of the present study

\begin{tabular}{|c|c|c|c|c|c|c|}
\hline \multirow[b]{2}{*}{ Points } & \multicolumn{3}{|c|}{ Temperature $\left({ }^{\circ} \mathrm{C}\right)$} & \multicolumn{3}{|c|}{ Humidity $\left(\mathrm{g}_{\text {water }} / \mathrm{kg}_{\text {air }}\right)$} \\
\hline & $\begin{array}{c}\text { Present } \\
\text { model }\end{array}$ & $\begin{array}{l}\text { Heidarinejad and } \\
\text { Pasdarshahri }[33]\end{array}$ & $\begin{array}{c}\text { Kodama } \\
\text { et al. }[32]\end{array}$ & $\begin{array}{c}\text { Present } \\
\text { model }\end{array}$ & $\begin{array}{l}\text { Heidarinejad and } \\
\text { Pasdarshahri }[33]\end{array}$ & $\begin{array}{l}\text { Kodama } \\
\text { et al. }[32]\end{array}$ \\
\hline 1 & 31 & 31 & 31 & 10.3 & 10.3 & 10.3 \\
\hline 2 & 54 & 55.2 & 55.5 & 4.35 & 4.46 & 4.4 \\
\hline 3 & 80 & 80 & 80 & 12.5 & 12.31 & 12.5 \\
\hline 4 & 57 & 55.83 & 56 & 18.2 & 18.14 & 18.10 \\
\hline
\end{tabular}
have been compared to those of the theoretical model of Bansal et al. [34,35] and the experimental results of Mathur et al. [28]; for different values of solar radiation, the following values of solar radiation (Figure 4) and different geometrical parameters of the wall have also been compared (Table 2).

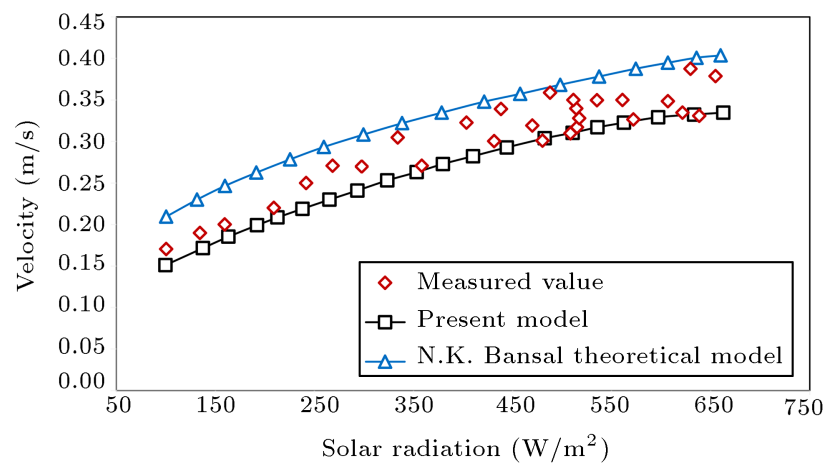

Figure 4. Comparison of the results of the present model, measured value, and theoretical model of N.K. Bansal in air gap $=0.30 \mathrm{~m}[34-36]$.

Table 1. Comparison temperature and humidity ratio at state points of the desiccant wheel. 
Table 2. The comparison of the present study and experimental results [28] for different air slits and channel heights of the Trombe wall.

\begin{tabular}{|c|c|c|c|c|c|c|c|c|c|}
\hline \multirow{2}{*}{$\begin{array}{l}\text { Absorber } \\
\text { height } \\
\text { (m) }\end{array}$} & \multirow{2}{*}{$\begin{array}{c}\text { Air slit } \\
\text { (m) }\end{array}$} & \multirow{2}{*}{$\begin{array}{l}\text { Channel } \\
\text { width } \\
(\mathrm{m})\end{array}$} & \multirow{2}{*}{$\begin{array}{l}\text { Channel } \\
\text { height } \\
(\mathrm{m})\end{array}$} & \multicolumn{2}{|c|}{$\begin{array}{c}\text { Air change } \\
\text { per hour } \\
\text { in } 300 \mathrm{~W} / \mathrm{m}^{2}\end{array}$} & \multicolumn{2}{|c|}{$\begin{array}{c}\text { Air change } \\
\text { per hour } \\
\text { in } 500 \mathrm{~W} / \mathrm{m}^{2}\end{array}$} & \multicolumn{2}{|c|}{$\begin{array}{c}\text { Air change } \\
\text { per hour } \\
\text { in } 700 \mathrm{~W} / \mathrm{m}^{2}\end{array}$} \\
\hline & & & & $\begin{array}{c}\text { Present } \\
\text { model }\end{array}$ & Exp. & $\begin{array}{c}\text { Present } \\
\text { model }\end{array}$ & Exp. & $\begin{array}{c}\text { Present } \\
\text { model }\end{array}$ & Exp. \\
\hline 0.90 & 0.1 & 0.1 & 0.95 & 2.14 & 2.0 & 2.51 & 2.40 & 2.71 & 2.662 \\
\hline 0.90 & 0.1 & 0.2 & 0.95 & 2.84 & 2.80 & 2.22 & 2.0 & 3.82 & 3.73 \\
\hline 0.90 & 0.1 & 0.3 & 0.95 & 2.42 & 2.40 & 2.71 & 2.66 & 3.13 & 2.93 \\
\hline 0.80 & 0.2 & 0.1 & 0.90 & 2.68 & 2.66 & 2.97 & 2.93 & 4.15 & 4.0 \\
\hline 0.80 & 0.2 & 0.2 & 0.90 & 4.55 & 4.53 & 4.33 & 4.26 & 3.84 & 3.73 \\
\hline $0 / 80$ & 0.2 & 0.3 & 0.90 & 5.42 & 5.33 & 4.72 & 4.53 & 5.42 & 5.33 \\
\hline $0 / 70$ & 0.3 & 0.1 & 0.85 & 3.30 & 3.20 & 4.17 & 4.0 & 4.52 & 4.40 \\
\hline 0.70 & 0.3 & 0.2 & 0.85 & 4.12 & 4.0 & 5.28 & 5.20 & 5.29 & 5.20 \\
\hline 0.70 & 0.3 & 0.3 & 0.85 & 4.23 & 4.40 & 4.92 & 4.80 & 5.64 & 5.60 \\
\hline
\end{tabular}

\section{Results and discussion}

According to the presented model, the desiccant wheel parameters, which are related to the area required for a Trombe wall, affect wheel exhaust air. Therefore, the effect of the area of the wall on the outlet parameters of the system has been presented and studied in this section. In order to examine the performance conditions on desiccant wheel with a Trombe wall and determine the impacts of wheel parameters on the required area for the wall, the parameters for designing a desiccant wheel are considered based on the initially assumed operating conditions, and the area required for the Trombe wall is achieved for different operating conditions. With respect to the comprehensive model outputs, the changes of the desiccant wheel parameters on the required area of the Trombe wall are studied. However, first of all, in order to study the effect of geometrical parameters of Trombe wall on the output variables of the wall and the desiccant wheel, it is necessary to consider solar intensity, which is available on different days of a year in the region (Gilan).

Figure 5 shows the amount of solar radiation during a year. In this figure, solar energy received by the Trombe wall is $600-740 \mathrm{~W} / \mathrm{m}^{2}$ (1 May- 15 August) in the warm and humid climate of Gilan (Iran). It is shown in advance that the solar radiation of $600 \mathrm{~W} / \mathrm{m}^{2}$ on Trombe wall can provide a regeneration air temperature of nearly $60^{\circ} \mathrm{C}$.

Figure 6 shows the variation of different temperatures related to the Trombe wall (output, flow, glass, and absorber temperature) as a function of solar intensity. In Figure 5, the highest output flow temperature is $60-70^{\circ} \mathrm{C}$, and this heated air can be used for regeneration of the desiccant wheel, because the humidity can be removed from the silica gel material of desiccant wheel by heat energy in the range of 60 $90^{\circ} \mathrm{C}[26]$.

Figure 7 shows the variations of airflow speed in the channel as a function of channel width. According

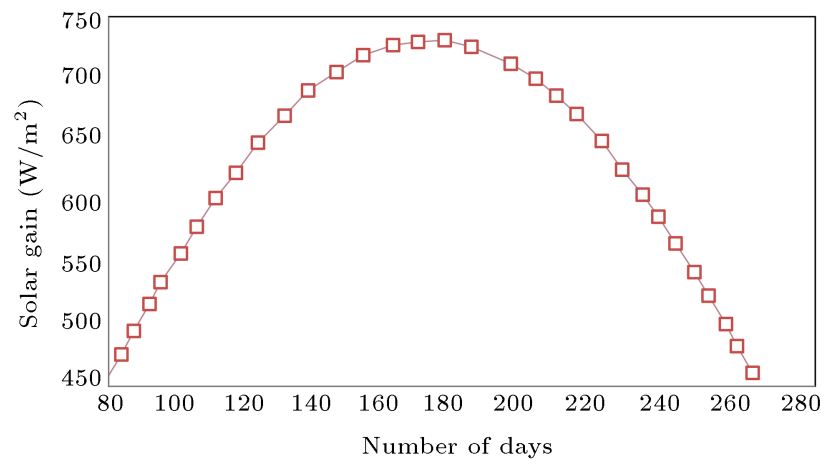

Figure 5. Solar energy variation during the year for Gilan.

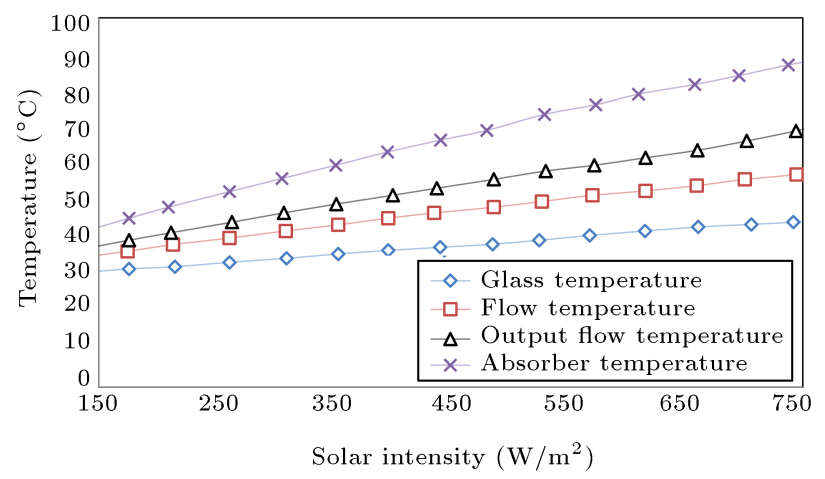

Figure 6. Temperature variation of the Trombe wall (output, flow, glass, and absorber temperature) as a function of solar intensity variation. 


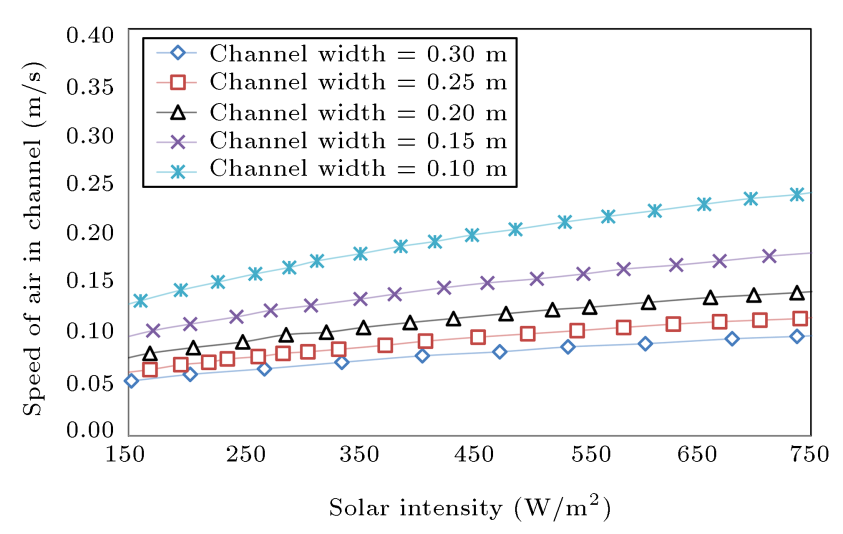

Figure 7. Variations of airflow speed in the channel as a function of channel width.

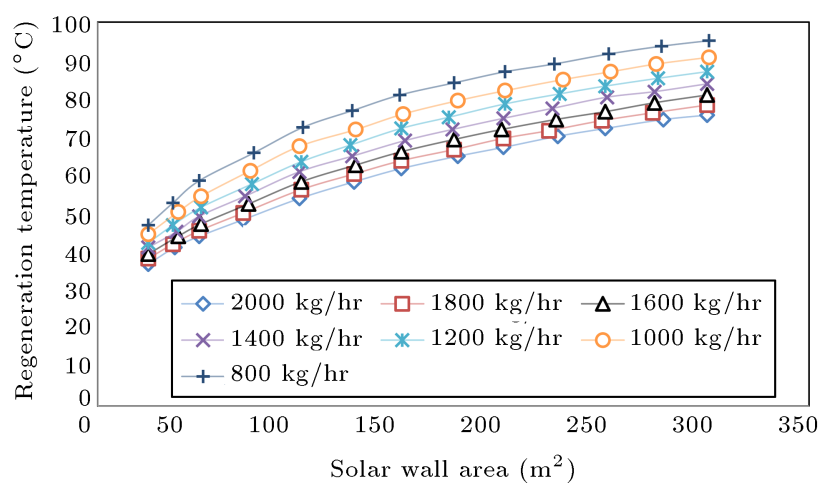

Figure 8. Variations of regeneration air temperature as a function of solar wall area and air flow rate in the channel.

to this figure, when the cross-section of the channel increases, the air flow rate and kinetic energy decrease. However, when solar thermal energy rises, the air flow temperature inside the channel increases and, due to differences in pressure and floating forces, the air velocity increases.

Figure 8 illustrates the variations of regeneration air temperature as a function of solar wall area and air flow rate in the channel. This figure shows that the regeneration air temperature increases with the size of the Trombe wall area. The area of $52 \mathrm{~m}^{2}$ of Trombe wall can provide a regeneration temperature of nearly $60^{\circ} \mathrm{C}$ with a flow rate ratio of $800 \mathrm{~kg} / \mathrm{hr}$. The same regeneration air temperature can be obtained by $125 \mathrm{~m}^{2}$ of the area with a flow rate ratio of $2000 \mathrm{~kg} / \mathrm{hr}$.

In Figure 9, the variations of regeneration temperature, ambient temperature, and wheel rotational speed as a function of various absorbent surface areas are shown. As deduced from Figure 9, the required Trombe wall area decreases with a rise in ambient temperature. As a result, a lower wall surface is required to increase the temperature. This figure shows that the optimal area required for the wall is $52 \mathrm{~m}^{2}$, as the wheel rotates at a speed of $27 \mathrm{RPH}$. In other words, considering the physical and geometric parameters of

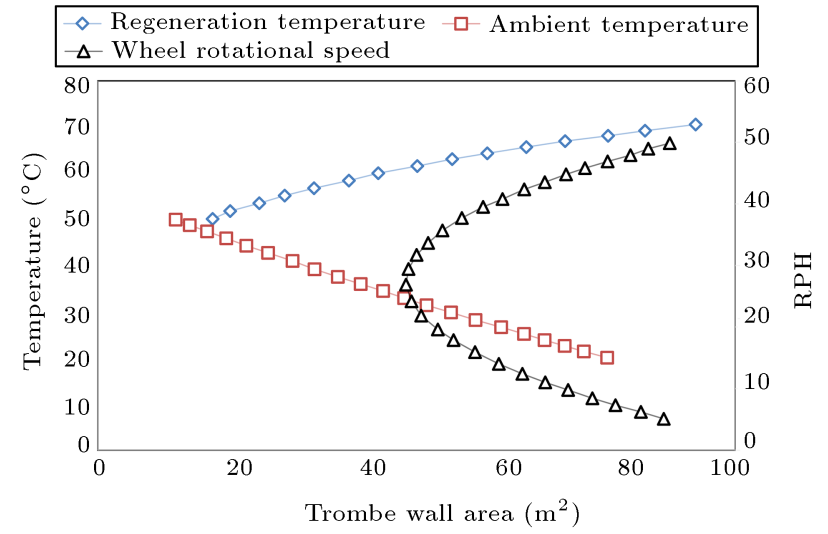

Figure 9. Variations of regeneration temperature, ambient temperature, and wheel rotational speed as a function of various absorbent surface areas.

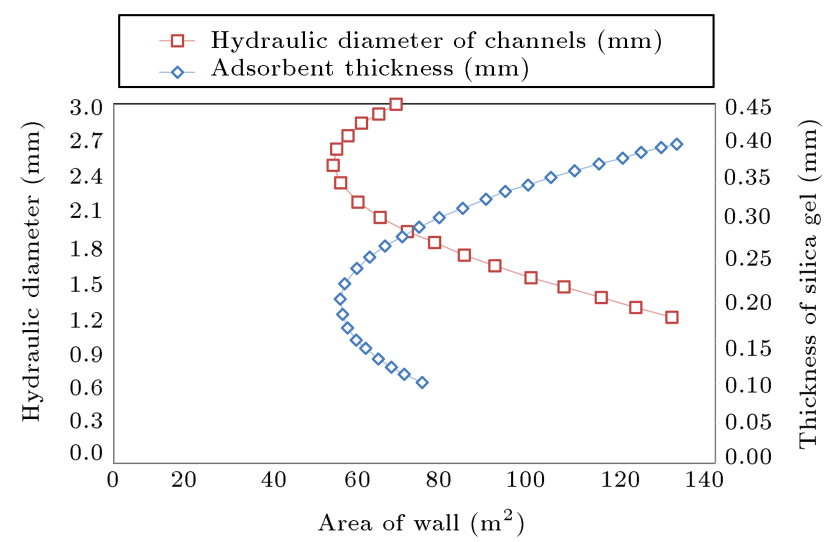

Figure 10. Variations of adsorbent thickness and hydraulic diameter as a function of various absorbent surface areas.

the wheel, the optimum speed for the wheel is 27 $\mathrm{RPH}$. If the wheel speed is high, the desiccant material will not have enough time to absorb moisture and will require a lot of energy to repair; therefore, the wall surface will increase; in addition, if the rotational speed is low, the material in the grid, which absorbs moisture, will have no capacity for absorbing moisture anymore, unless the thermal energy increases through regeneration by increasing the wall surface.

The variations of adsorbent thickness and hydraulic diameter as a function of various absorbent surface areas are shown in Figure 10. Figure 10 shows that, for the $0.2 \mathrm{~mm}$ thickness of silica gel, the optimal wall area is $52 \mathrm{~m}^{2}$. When the thickness of the silica gel material increases, the amount of moisture absorbed in this material increases; in other words, moisture and air vapor penetrate into the depth of the silica gel material and, therefore, restore a lot of energy to the material and a large amount of wall area is needed. Moreover, Figure 9 shows that the required wall surface is $52 \mathrm{~m}^{2}$ for a hydraulic diameter of $2.5 \mathrm{~mm}$. When 


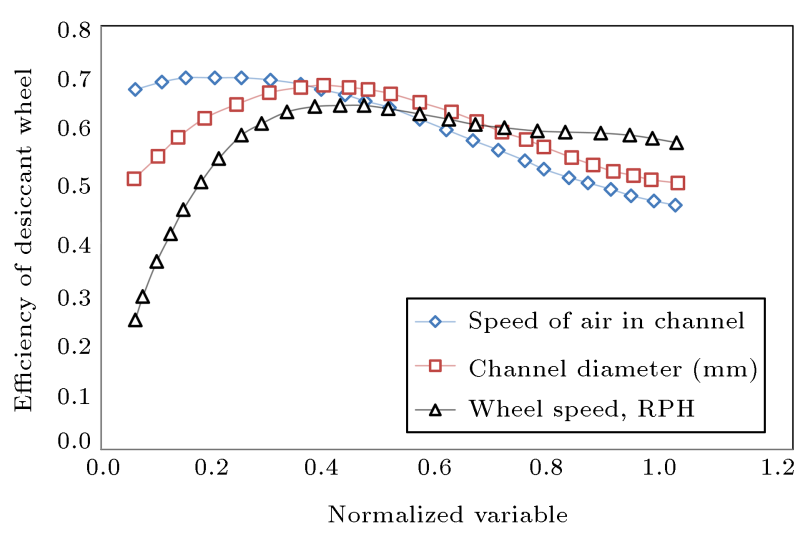

Figure 11. Variations of the efficiency of desiccant wheel as a function of input values (normalized variable $=$ variable/maximum of the variable).

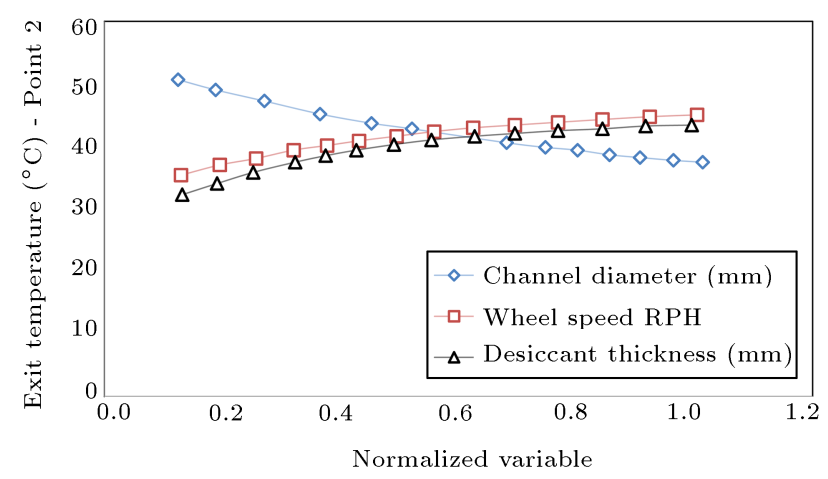

Figure 12. Variations of exit temperature from the desiccant wheel as a function of input values (normalized variable $=$ variable $/$ maximum of the variable).

the hydraulic diameter is less than the desired value of $2.5 \mathrm{~mm}$, thermal energy must penetrate the desiccant wheel matrix pores; therefore, the Trombe wall area has increased to provide this extra energy. If the hydraulic diameter is also optimized, more regeneration energy will pass through the desiccant wheel matrix, and the possibility of lower contact with silica gel will be provided; as a result, the thermal energy increases again and the system requires more area for the wall.

In Figures 11 and 12, the efficiency of the desiccant wheel and the wheel output temperature are shown based on the regeneration temperature by the Trombe wall. Figure 11 shows the efficiency of the desiccant wheel as a function of normalized speed of the air in the channel, channel diameter ( $\mathrm{mm})$, and wheel speed $(\mathrm{RPH})$. Further, changes in outlet temperature and wheel coefficient are shown based on changes in the initial values in Figure 12. According to this figures, an increase in the input variables to the optimal values leads to an increase in the efficiency of the desiccant wheel, and a further increase in the input values causes a reduction in efficiency of the wheel. The reason for this phenomenon has been partly described before: in a higher wheel speed, there will not be enough time for the desiccant material to absorb moisture; if the rotational speed is low, the material in the grid, which absorbs moisture, will have no capacity for absorbing more moisture. The same reason holds for the variation of efficiency as a function of speed of the air in the channel and channel diameter.

\section{Conclusion}

In the present study, a novel Trombe-wall-assisted desiccant system was modeled, in which the Trombe wall was divided into three equal parts. The energy required for the regeneration of the desiccant wheel was provided. The Trombe wall area was determined through a comprehensive analysis of different aspects of the problem.

The area of the Trombe wall was extracted and depicted as a function of various parameters of desiccant wheel to represent a mathematical approach to the optimization of the area. With respect to the optimal design parameters, the optimal area required for the Trombe wall is determined. Apart from novelties in the design and analysis of the presented desiccant wheel system, some of the results can be summarized as follows:

- Solar energy received by the Trombe wall is 600$740 \mathrm{~W} / \mathrm{m}^{2}$ (1 May-15 August) in the warm and humid climate of Gilan (Iran). The solar radiation of $600 \mathrm{~W} / \mathrm{m}^{2}$ on Trombe wall can provide a regeneration air temperature of nearly $60^{\circ} \mathrm{C}$;

- The solar radiation of $600-740 \mathrm{~W} / \mathrm{m}^{2}$ on Trombe wall can provide the wall surface temperature in the range of $77-86^{\circ} \mathrm{C}$, and this temperature can provide the outlet regeneration air temperature in the range of $60-70^{\circ} \mathrm{C}$;

- The Trombe wall area is considered $52 \mathrm{~m}^{2}$ at an optimum desiccant wheel rotational speed of 27 RPM;

- With respect to the absorbent thickness of desiccant wheel $(0.2 \mathrm{~mm})$, the area required for the wall is considered $52 \mathrm{~m}^{2}$;

- The hydraulic diameter of the channels, transferring humid air of the desiccant wheel, becomes $2.5 \mathrm{~mm}$, and the required area for the wall is $52 \mathrm{~m}^{2}$;

- The output humidity of the desiccant wheel is reduced from $23 \mathrm{~g}_{w} / \mathrm{kg}_{a}$ to $10-12 \mathrm{~g}_{w} / \mathrm{kg}_{a}$ in the studied region (Gilan, Iran).

\section{Nomenclature}

$\begin{array}{ll}A & \text { Area }\left(\mathrm{m}^{2}\right) \\ C_{p} & \text { Specific heat }(\mathrm{J} / \mathrm{k}) \\ D_{h} & \text { Hydraulic diameter }(\mathrm{mm})\end{array}$




\begin{tabular}{|c|c|}
\hline$d t$ & Thickness of the desiccant (mm) \\
\hline$G s c$ & Solar constant $\left(\mathrm{W} / \mathrm{m}^{2}\right)$ \\
\hline$h$ & Heat transfer coefficient $\left(\mathrm{W} / \mathrm{m}^{2} \mathrm{~K}\right)$ \\
\hline$I$ & Solar radiation incident $\left(\mathrm{W} / \mathrm{m}^{2}\right)$ \\
\hline$L$ & Thickness of glass (mm) \\
\hline$m$ & Mass flow rate $(\mathrm{kg} / \mathrm{s})$ \\
\hline$N$ & Wheel speed (RPH) \\
\hline$S$ & Solar radiation $\left(\mathrm{W} / \mathrm{m}^{2}\right)$ \\
\hline$T$ & Temperature $\left({ }^{\circ} \mathrm{C}\right)$ \\
\hline$U$ & Velocity of air $(\mathrm{m} / \mathrm{s})$ \\
\hline$U t$ & Heat transfer coefficient $(\mathrm{W} / \mathrm{mK})$ \\
\hline$K$ & Thermal conductivity \\
\hline $\mathrm{Nu}$ & Nusselt number \\
\hline $\operatorname{Pr}$ & Prandtl number \\
\hline$q$ & Heat transfer (W) \\
\hline $\mathrm{R}_{\mathrm{a}}$ & Rayleigh number \\
\hline $\mathrm{R}_{\mathrm{b}}$ & Geometric factor \\
\hline$\alpha$ & Absorptance \\
\hline$\tau$ & Transmittance \\
\hline$\omega$ & Humidity ratio $\left(\mathrm{g}_{\mathrm{w}} / \mathrm{kg}_{\mathrm{a}}\right)$ \\
\hline$\gamma$ & Temperature weight factor \\
\hline$\varepsilon$ & Effectiveness \\
\hline$\Phi$ & Relative humidity \\
\hline$\mu$ & Viscosity (kg/s. m) \\
\hline$\rho$ & Density $\left(\mathrm{kg} / \mathrm{m}^{3}\right)$ \\
\hline$\sigma$ & Stefan-Boltzmann constant \\
\hline $\mathrm{db}$ & Dry bulb \\
\hline In & Inlet \\
\hline $\operatorname{Reg}$ & Regeneration \\
\hline$W b$. & Wet bulb \\
\hline$a$ & Air \\
\hline Cond. & Conduction \\
\hline Cony. & Convection \\
\hline
\end{tabular}

\section{References}

1. Ge, T., Dai, Y., and Wang, R. "Review on solar powered rotary desiccant wheel cooling system", Renewable and Sustainable Energy Reviews, 39, pp. 476497 (2014).

2. Jani, D., Mishra, M., and Sahoo, P. "Solid desiccant air conditioning-a state of the art review", Renewable and Sustainable Energy Reviews, 60, pp. 1451-1469 (2016).

3. Jani, D., Mishra, M., and Sahoo, P. "A critical review on application of solar energy as renewable regeneration heat source in solid desiccant-vapor compression hybrid cooling system", Journal of Building Engineering, 18, pp. 107-124 (2018).

4. Hatami, Z., Saidi, M.H., Mohammadian, M., and Aghanajafi, C. "Optimization of solar collector surface in solar desiccant wheel cycle", Energy and Buildings, 45, pp. 197-201 (2012).

5. Tsujiguchi, T., Osaka, Y., and Kodama, A. "Feasibility study of simultaneous heating and dehumidification using an adsorbent desiccant wheel with humidity swing", Applied Thermal Engineering, 117, pp. 437442 (2017).

6. Kabeel, A. and Abdelgaied, M. "Solar energy assisted desiccant air conditioning system with PCM as a thermal storage medium", Renewable Energy, 122, pp. 632-642 (2018).

7. Das, R.S. and Jain, S. "Experimental investigations on a solar assisted liquid desiccant cooling system with indirect contact dehumidifier", Solar Energy, 153, pp. 289-300 (2017).

8. Nie, J., Li, Z., Hu, W., Fang, L., and Zhang, Q. "Theoretical modelling and experimental study of air thermal conditioning process of a heat pump assisted solid desiccant cooling system", Energy and Buildings, 153, pp. 31-40 (2017).

9. Gadalla, M. and Saghafifar, M. "Performance assessment and transient optimization of air precooling in multi-stage solid desiccant air conditioning systems", Energy Conversion and Management, 119, pp. 187-202 (2016).

10. Kumar, A. and Yadav, A. "Experimental investigation of solar-powered desiccant cooling system by using composite desiccant "CaCl2/jute"", Environment, Development and Sustainability, 19(4), pp. 1279-1292 (2017).

11. Ahmadzadehtalatapeh, M. "Solar assisted desiccant evaporative cooling system for office buildings in Iran: a yearly simulation model", Scientia Iranica, 25(1), pp. 280-298 (2018).

12. El-Agouz, S. and Kabeel, A. "Performance of desiccant air conditioning system with geothermal energy under different climatic conditions", Energy Conversion and Management, 88, pp. 464-475 (2014).

13. Wrobel, J., Walter, P.S., and Schmitz, G. "Performance of a solar assisted air conditioning system at different locations", Solar Energy, 92, pp. 69-83 (2013).

14. Sopian, K., Dezfouli, M., Mat, S., and Ruslan, M. "Solar assisted desiccant air conditioning system for hot and humid areas", International Journal of Environment and Sustainability, 3(1), pp. 23-32 (2014).

15. Abbassi, Y., Baniasadi, E., and Ahmadikia, H. "Comparative performance analysis of different solar desiccant dehumidification systems", Energy and Buildings, 150, pp. 37-51 (2017).

16. Salarian, H., Ghorbani, B., Amidpour, M., and Salehi, G. "Performance study on dehumidifier of packed bed liquid desiccant system", Scientia Iranica, 21(1), pp. 222-228 (2014).

17. Jani, D., Mishra, M., and Sahoo, P. "Experimental investigation on solid desiccant-vapor compressionhybrid air-conditioning system in hot and humid 
weather", Applied Thermal Engineering, 104, pp. 556564 (2016).

18. Jani, D., Mishra, M., and Sahoo, P. "Performance prediction of rotary solid desiccant dehumidifier in hybrid air-conditioning system using artificial neural network", Applied Thermal Engineering, 98, pp. 10911103 (2016).

19. Jani, D., Mishra, M., and Sahoo, P. "Performance prediction of solid desiccant-vapor compression hybrid airconditioning system using artificial neural network", Energy, 103, pp. 618-629 (2016).

20. Jani, D., Mishra, M., and Sahoo, P. "Performance studies of hybrid solid desiccant-vapor compression air-conditioning system for hot and humid climates", Energy and Buildings, 102, pp. 284-292 (2015).

21. Stritih, U. and Medved, S. "Use of phase change materials in the wall with TIM", Strojniški Vestnik-Journal of Mechanical Engineering, 40(3-4), p. 6 (1994).

22. Shen, J., Lassue, S., Zalewski, L., and Huang, D. "Numerical study on thermal behavior of classical or composite Trombe solar walls", Energy and Buildings, 39(8), pp. 962-974 (2007).

23. Fernández-González, A. "Analysis of the thermal performance and comfort conditions produced by five different passive solar heating strategies in the United States Midwest", Solar Energy, 81(5), pp. 581-593 (2007).

24. Stazi, F., Di Perna, C., Filiaci, C., and Stazi, A. "The solar wall in the Italian climates", World Academy of Science, Engineering and Technology, 37, pp. 31-39 (2008).

25. Stazi, F., Mastrucci, A., and di Perna, C. "The behaviour of solar walls in residential buildings with different insulation levels: an experimental and numerical study", Energy and Buildings, 47, pp. 217-229 (2012).

26. Ahmed, M., Kattab, N., and Fouad, M. "Evaluation and optimization of solar desiccant wheel performance", Renewable Energy, 30(3), pp. 305-325 (2005).

27. Esfandiari Nia, F., van Paassen, D., and Saidi, M.H. "Modeling and simulation of desiccant wheel for air conditioning", Energy and Buildings, 38(10), pp. 12301239 (2006).

28. Mathur, J., Bansal, N., Mathur, S., and Jain, M. "Experimental investigations on solar chimney for room ventilation", Solar Energy, 80(8), pp. 927-935 (2006).

29. Patankar, S., Numerical Heat Transfer and Fluid Flow, CRC press (1980).

30. Duffie, J.A. and Beckman, W.A., Solar Engineering of Thermal Processes, John Wiley \& Sons (2013).

31. Holman, J., Heat transfer, McGraw-Hill Book Company, Soythern Methodist University (1986).

32. Kodama, A., Hirayama, T., Goto, M., Hirose, T., and Critoph, R. "The use of psychrometric charts for the optimisation of a thermal swing desiccant wheel",
Applied Thermal Engineering, 21(16), pp. 1657-1674 (2001).

33. Heidarinejad, G. and Pasdarshahri, H. "The effects of operational conditions of the desiccant wheel on the performance of desiccant cooling cycles", Energy and Buildings, 42(12), pp. 2416-2423 (2010).

34. Bansal, N., Mathur, J., Mathur, S., and Jain, M. "Modeling of window-sized solar chimneys for ventilation", Building and Environment, 40(10), pp. 13021308 (2005).

35. Bansal, N.K., Mathur, R., and Bhandari, M.S. "Solar chimney for enhanced stack ventilation", Building and Environment, 28(3), pp. 373-377 (1993).

36. Bansal, N., Mathur, R., and Bhandari, M. "A study of solar chimney assisted wind tower system for natural ventilation in buildings", Building and Environment, 29(4), pp. 495-500 (1994).

\section{Biographies}

Moharam Bahramkhoo is a PhD Candidate in Energy Engineering from Science and Research Branch, Islamic Azad University, Tehran, Iran. He has received his Bachelor of Science in Mechanical Engineering from University of Guilan, Rasht, Iran (1999-2004) and his MSc degree in Energy Engineering from Science and Research Branch, Islamic Azad University, Tehran, Iran (2006-2009).

Kourosh Javaherdeh is an Associate Professor. He currently works at the faculty of Mechanical Engineering, University of Guilan, Rasht, Iran. Their current project is 'heat transfer in non-Newtonian fluids and thermodynamics'. He has received his Bachelor of Science in Mechanical Engineering from Ferdowsi University of Mashhad, Iran (1983-1987) and obtained his MSc and PhD degrees in Mechanical Engineering from National Polytechnic Institute of Lorraine, France (1991-1993) and National Polytechnic Institute of Nancy, France (1993-1996).

Farideh Atabi is an Associate Professor at the Environmental Engineering Department at Science and Research Branch of Islamic Azad University. She has received her Bachelor of Science in Mechanical Engineering and obtained her $\mathrm{MSc}$ and $\mathrm{PhD}$ degrees in Environmental Engineering. Providing education and supervision of numerous $\mathrm{MSc}$ and $\mathrm{PhD}$ research projects, she has worked as a University Professor for 21 years. She has had cooperation with national and international organizations and research institutes and has been also the board member of Iran Energy Association (IEA) for 8 years. Her research work focuses on air pollution monitoring and modeling, renewable energy, and energy efficiency. She has more than 100 publications in national and international 
journals and over 70 conference papers presented at national and international conferences.

Abolghasem Emamzadeh holds his PhD in Applied
Mathematics from the University of Wales, UK. He
worked as an Instructor in the Abadan Institute of
Technology (AIT), Training and Educational Estab-
lishment located in Abadan and affiliated to the Na-
tional Iranian Oil Company (NIOC). The courses in this institute served Petroleum, Gas, and Petrochemical industry. Then, he worked as the General Manager of Research Institute of Petroleum Industry (RIPI), an Institute that serves all R\&D of petroleum, gas, and petrochemistry. Later, he worked as the Director of joint Master programs in petroleum engineering with University of Calgary, Canada, Curtin University of Technology, Australia and Institute France du Petrol, France. 